\title{
K-252a: A Specific Inhibitor of the Action of Nerve Growth Factor on PC12 Cells
}

\author{
Shinichi Koizumi, Margarita L. Contreras, Yuzuru Matsuda, ${ }^{a}$ Tokiko Hama, \\ Philip Lazarovici, and Gordon Guroff \\ Section on Growth Factors, National Institutes of Child Health and Human Development, National Institutes of Health, \\ Bethesda, Maryland 20892
}

\begin{abstract}
K-252a, a kinase inhibitor isolated from the culture broth of Nocardiopsis sp., selectively inhibits the actions of nerve growth factor (NGF) on PC12 cells. At a concentration of 200 nM, K-252a prevents neurite generation initiated by NGF, but not neurite generation produced by fibroblast growth factor or outgrowth produced by dibutyryl CAMP. K-252a also inhibits the induction of ornithine decarboxylase by NGF, but stimulates ornithine decarboxylase induction by epidermal growth factor. Stimulation of phosphatidylinositol breakdown by NGF was similarly inhibited by K-252a, while stimulation by epidermal growth factor was enhanced. The NGFinduced decrease in the phosphorylation of a soluble protein, Nsp 100, was prevented by K-252a. K-252a blocks the NGF-induced heterodown-regulation of the epidermal growth factor receptor, but not the epidermal growth factorinduced homodown-regulation of the epidermal growth factor receptor. K-252a, then, provides a new tool for the dissection and study of NGF-requiring processes.
\end{abstract}

Nerve growth factor (NGF) is required for the survival and development of the sympathetic and certain of the sensory neurons (Levi-Montalcini, 1966; Greene and Shooter, 1980). More recently, it has been shown that chromaffin cells in the adrenal medulla respond morphologically to NGF (Unsicker et al., 1978; Aloe and Levi-Montalcini, 1979) and that certain cholinergic neurons in the central nervous system exhibit biochemical responses to the factor (Hefti et al., 1985; Martinez et al., 1985). The PC1 2 cells, a clonal population arising from a tumor of the rat adrenal medulla, have proven to be a most useful and increasingly popular model for the study of the actions of NGF (Greene and Tischler, 1982; Guroff, 1984). While not requiring NGF for outright survival, the PC12 cells undergo a profound and easily observable differentiation under its influence. In the presence of nanomolar amounts of NGF, the cells stop dividing, elaborate neurites, become electrically excitable (Greene and Tischler, 1976), and will form synapses with appropriatc muscle cells in culture (Schubert et al., 1977). Indeed, in broad outline, the process can be described as the conversion of a chromaffin cell into a sympathetic neuron.

\footnotetext{
Received Mar. 18, 1987; revised June 29, 1987; accepted Aug. 25, 1987.

Correspondence should be addressed to Dr. Gordon Guroff, Chief, Section on Growth Factors, National Institute of Child Health and Human Development, National Institutes of Health, Bldg. 6, Rm. 1A07, Bethesda, MD 20892.

a Present address: Kyowa Hakko Kogyo Co., Ltd., Tokyo Research Laboratories 3-6-6, Asahi-machi, Machida-shi, Tokyo 194, Japan.

0270-6474/88/020715-07\$02.00/0
}

The PC1 2 cells have been the subject of most of the recent studies on the molecular mechanisms by which NGF acts. The details of this action are not clear as yet, but it appears increasingly likely that at least one means by which NGF acts is by altering the level of phosphorylation of a number of cellular proteins (Halegoua and Patrick, 1980; Yu et al., 1980; End et al., 1983; Landreth and Rieser, 1985; Lee et al., 1985; Matsuda et al., 1986). It is clear, from more recent studies, that the changes seen in the various phosphorylations in NGF-sensitive cells are due to the actions of more than one kinase. At least 2 kinases are involved in the NGF-stimulated increase in the phosphorylation of tyrosine hydroxylase (Cremins et al., 1986); protein kinase $\mathrm{C}$ is part of the NGF-inhibited pathway leading to the phosphorylation of Nsp100 (Hama et al., 1986), and a cAMP-dependent kinase appears to be involved in the NGFstimulated phosphorylation of the ribosomal protein S6 (Matsuda and Guroff, 1987). In addition, there are NGF-initiated alterations in a number of apparently more specific kinases that directly phosphorylate proteins in various compartments of the cells, e.g., Nsp 100 kinase (Togari and Guroff, 1985), SMP kinase (Nakanishi and Guroff, 1985), and S6 kinase (Matsuda and Guroff, 1987). Thus, a number of kinases seem to subserve the various actions of NGF in responsive cells. The ability to alter the actions of these various kinases selectively is a necessary part of any effort to dissect the actions of NGF in a biochemical sense.

Another important consideration is that a number of other factors have actions on $\mathrm{PC} 12$ cells, actions that, in many cases, parallel those of NGF. For example, epidermal growth factor (EGF) will increase ornithine decarboxylase activity (Huff et al., 1981) and induce a battery of oncogenes (Greenberg et al., 1985), as does NGF, but epidermal growth factor is a mild mitogen for PC12 cells and does not elicit neurite outgrowth. Fibroblast growth factor (FGF) will produce neurite outgrowth (Togari et al., 1985) similar to that produced by NGF, and dibutyryl cyclic AMP (dBcAMP) produccs an outgrowth that has different characteristics from that produced by NGF (Gunning et al., 1981). Inhibitors specific for the kinases peculiar to the actions of NGF could allow a differentiation between the actions of these various ligands and a definition of their mechanisms of action.

$\mathrm{K}-252 \mathrm{a}$, an alkaloid-like material isolated from the culture broth of Nocardiopsis sp., has been found to be a potent inhibitor of protein kinase C (Kase et al., 1986). Because of our previous observation (Hama et al., 1986) that protein kinase $\mathrm{C}$ is involved in at least one intracellular pathway altered by NGF treatment of $\mathrm{PC} 12$ cells, we were interested in exploring the effects of 

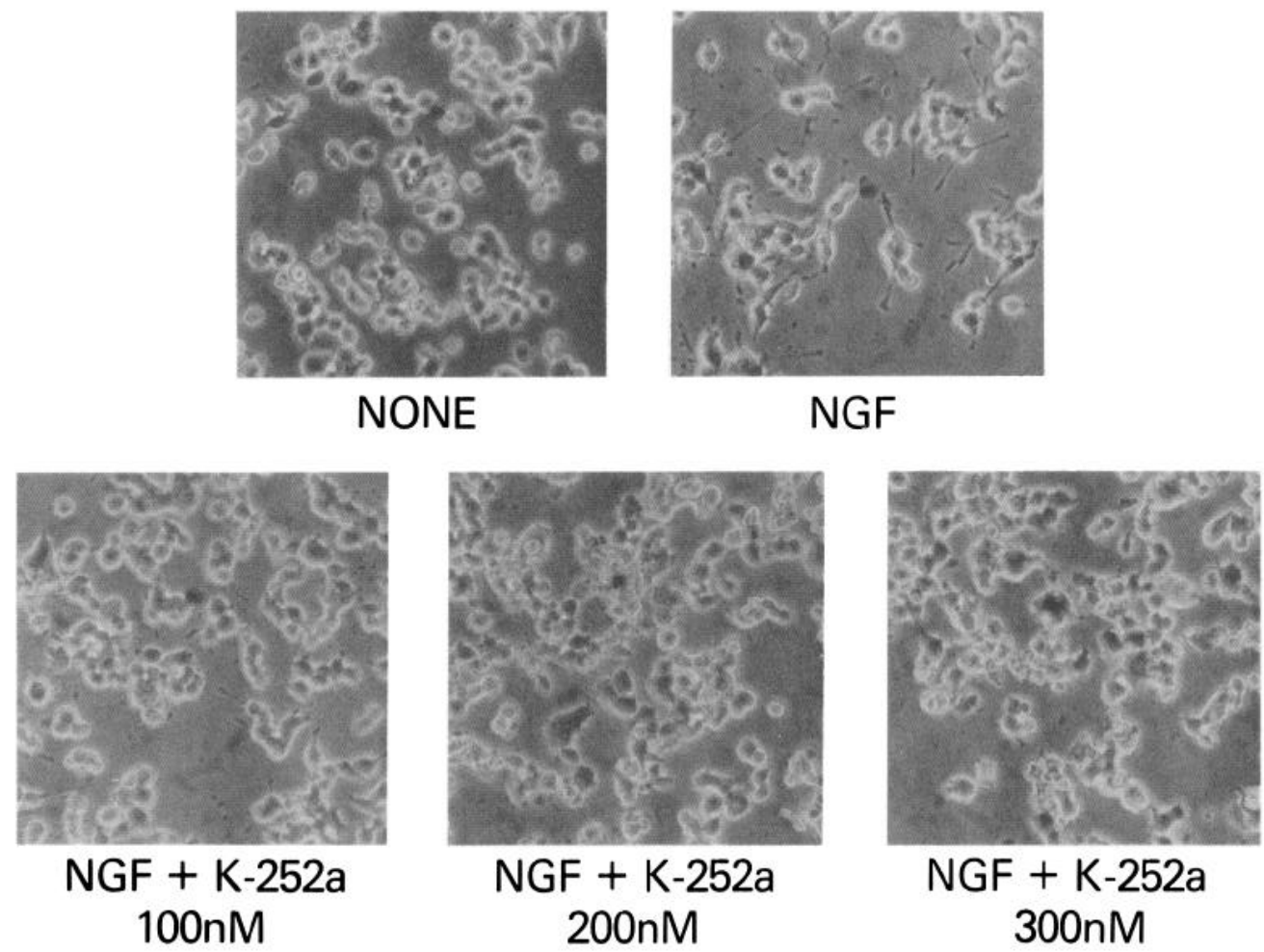

Figure 1. The inhibition of NGF-induced neurite outgrowth by K-252a. Cells were treated with $\mathrm{NGF}(50 \mathrm{ng} / \mathrm{ml})$ and the indicated amount of $\mathrm{K}-252 \mathrm{a}$ for $48 \mathrm{hr}$.

$\mathrm{K}-252 \mathrm{a}$ on the various actions of NGF on these cells. In this paper, we present our findings with this compound and detail the intriguing observation that this material is a specific inhibitor of the actions of NGF on these cells.

\section{Materials and Methods}

Materials. NGF was prepared according to the method of Bocchini and Angeletti (1969). EGF and FGF were obtained from Collaborative Research. Twelve- $O$-tetradecanoylphorbol-13-acetate (TPA) and $N, 2^{\prime}$-dibutyryladenosine $3^{\prime}, 5^{\prime}$-cyclic monophosphate (dBcAMP) were purchased from Sigma. K-252a was a gift from Kyowa Hakko Kogyo Co. (Tokyo). L-1-14 C-Ornithine hydrochloride was obtained from Amersham and ${ }^{3} \mathrm{H}$-inositol was purchased from American Radiolabeled Chemicals. All other chemicals were of reagent grade.

Cell culture. PC12 cells were grown as monolayers at $37^{\circ} \mathrm{C}$ in $6 \% \mathrm{CO}_{2}$ in Dulbecco's modified Eagle's medium (DMEM; Gibco), supplemented with $7 \%$ fetal bovine serum, $7 \%$ horse serum, and $100 \mu \mathrm{g}$ of streptomycin and $100 \mathrm{U}$ of penicillin $/ \mathrm{ml}$. The cells were split in a 1:6 ratio each week and the medium changed once between each split.

Addition of $K-252 a$. A stock solution of K-252a ( $2 \mathrm{~mm}$ ) was prepared in dimethylsulfoxide and stored at $-20^{\circ} \mathrm{C}$ in the dark. The stock solution was diluted 1:100 with culture medium or PBS just before use and added to the culture medium. The final concentration of dimethylsulfoxide was $0.01 \%$, a concentration that had no effect on any of the parameters of PC12 function observed here. Dimethylsulfoxide in a similar concentration was used in the control cultures.

Assay of ornithine decarboxylase (ODC) activity. ODC activity was measured by the method of Pegg and Williams-Ashman (1968), as modified by Oka and Perry (1976), and described in detail in a previous publication from this laboratory (Huff et al., 1981).

Measurement of phosphoinositide turnover. For experiments on phosphoinositide turnover, PC1 2 cells were grown in DMEM containing the usual additives, except that the fetal bovine serum was treated with charcoal by the procedure of Armelin et al. (1974). The measurement of phosphoinositide turnover was performed as previously described (Contreras and Guroff, 1987). PC12 cells were preincubated in growth medium lacking inositol, but with ${ }^{3} \mathrm{H}$-inositol $(0.4 \mu \mathrm{Ci} / \mathrm{ml})$ for $40-48$ $\mathrm{hr}$. Prior to the assay the growth medium was removed and the cells were incubated in PBS containing $10 \mathrm{~mm}$ lithium in the presence or absence of K-252a for $10 \mathrm{~min}$. The assay was initiated by the addition of the test compound and terminated, after incubation at $37^{\circ} \mathrm{C}$ for 15 min, by the addition of ice-cold PBS. The cells were collected by centrifugation and resuspended in $1 \mathrm{ml}$ of $5 \mathrm{~mm}$ Tris- $\mathrm{HCl}(\mathrm{pH} 8.0)$. After removal of lipids by extraction with $2 \mathrm{ml}$ of choloroform : methanol (1: 1), the aqueous layer was subjected to chromatography on AG 1-X8 (200-400 mesh, formate form) (Bio-Rad), and the phosphoinositides were eluted according to the method of Berridge et al. (1983).

Measurement of epidermal growth factor receptors. Cell-associated specific binding of ${ }^{125} \mathrm{I}$-EGF was measured by adding labeled EGF $(1 \times$ $10^{5} \mathrm{cpm} / \mathrm{ml}, 80 \mathrm{pg} / \mathrm{ml}$ ) to subconfluent monolayers of PC12 cells in 2 $\mathrm{ml}$ of fresh growth medium. The cells were incubated at $37^{\circ} \mathrm{C}$ for 45 $\mathrm{min}$, after which the radioactive medium was removed. The monolayers were washed twice with fresh medium and twice with PBS. The cells were solubilized in $0.5 \mathrm{M} \mathrm{NaOH}$ and the cell-associated radioactivity measured. A portion was reserved for protein determination. Nonspecific binding was measured in the presence of $1 \times 10^{-7} \mathrm{M}$ of unlabeled EGF and was usually about $5 \%$ of the total binding. All binding experiments were done in triplicate and the data are presented as the mean $\pm \mathrm{SD}$. Heterodown- and homodown-regulation of EGF receptors was performed as described by Lazarovici et al. (1987).

Iodination and binding of NGF. NGF was iodinated by a modification of the procedure of Sutter et al. (1979). The reagents were added to a microcentrifuge tube in the following order: $5.6 \mu \mathrm{l}$ of ${ }^{125} \mathrm{I}$ (approximately $2 \mu \mathrm{Ci}), 12 \mu \mathrm{l}$ of NGF $(1.67 \mu \mathrm{g} / \mu \mathrm{l}), 10 \mu \mathrm{l}$ of lactoperoxidase $(30 \mu \mathrm{g} / \mathrm{ml})$, $10 \mu \mathrm{l}$ of a $1: 10^{4}$ dilution of $30 \% \mathrm{H}_{2} \mathrm{O}_{2}$, and $27.4 \mu \mathrm{l}$ of $0.1 \mathrm{M}$ phosphate buffer, $\mathrm{pH}$ 7.4. After $30 \mathrm{~min}$, another $10 \mu \mathrm{l}$ of diluted $\mathrm{H}_{2} \mathrm{O}_{2}$ was added. A third portion was added after $30 \mathrm{~min}$ to bring the total volume to 75 $\mu \mathrm{l}$. The reaction was terminated $30 \mathrm{~min}$ later by the addition of $75 \mu \mathrm{l}$ of $0.4 \%$ acetic acid. Approximately $90-95 \%$ of the radioactivity was associated with the NGF at this stage. To purify the ${ }^{125}$ I-NGF further by removing residual free iodine and the high-molecular-weight aggregates of ${ }^{125} \mathrm{I}-\mathrm{NGF}, 300 \mu \mathrm{l}$ of $0.05 \mathrm{~m}$ sodium acetate buffer containing $0.15 \mathrm{M} \mathrm{NaCl}, 0.1 \% \mathrm{BSA}, 0.5 \%$ cytochrome c, and $0.05 \%$ phenol red, $\mathrm{pH} 4.0$, were added to the mixture. The solution was placed on a $30 \times$ $1 \mathrm{~cm}$ column of Biogel P6. The ${ }^{125} \mathrm{I}-\mathrm{NGF}$ was eluted from the column with $0.05 \mathrm{M}$ sodium acetate buffer containing $0.15 \mathrm{M} \mathrm{NaCl}$ and $0.1 \%$ BSA. The fractions collected were those that contained the cytochrome c, before the phenol red. At least $95 \%$ of the radioactivity was precipitable with trichloracetic acid and the specific activity, calculated by the method of Vale and Shooter (1985), was $147 \mathrm{cpm} / \mathrm{pg}$.

PC1 2 cells were plated onto $35 \mathrm{~mm}$ dishes for the binding assay. The cells were washed twice with DMEM containing $0.1 \%$ BSA. Cells were 

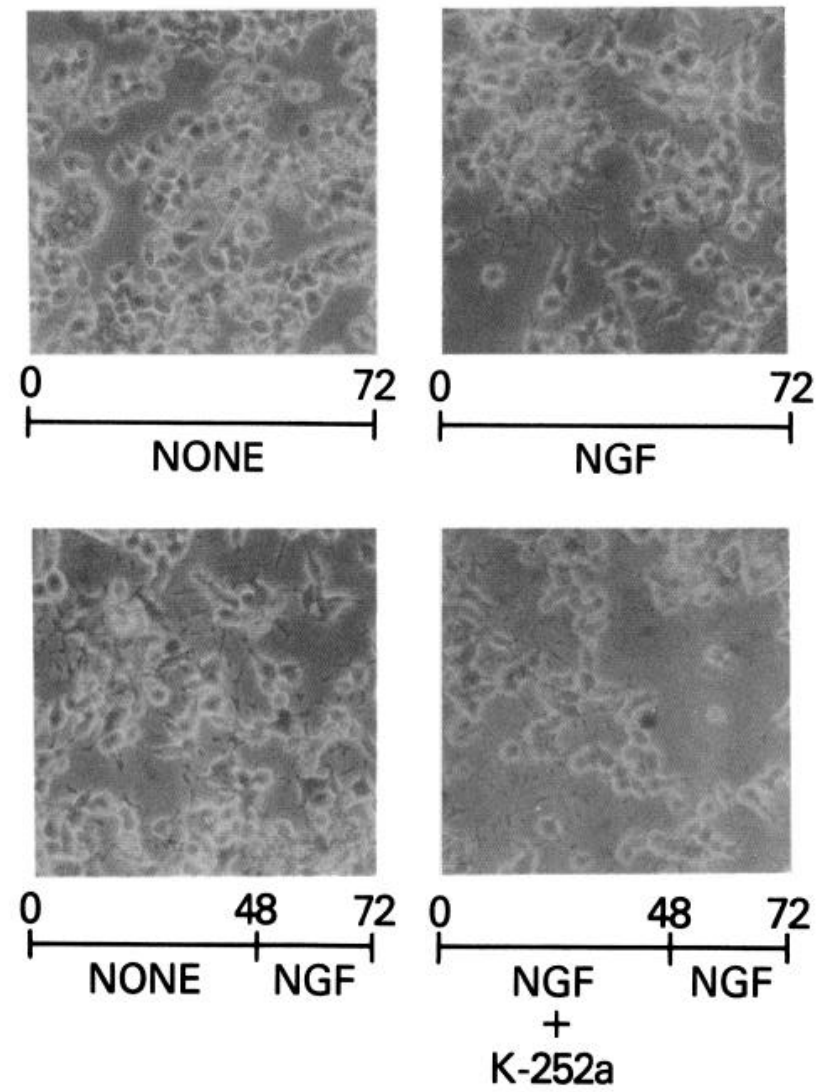

Figure 2. Reversibility of the inhibition of neurite outgrowth by $\mathrm{K}-252 \mathrm{a}$. Cells were grown for the indicated time in the presence or absence of NGF ( $50 \mathrm{ng} / \mathrm{ml})$ and/or $200 \mathrm{~nm} \mathrm{K-252a.}$ incubated with ${ }^{125} \mathrm{I}-\mathrm{NGF}$ in a total volume of $1 \mathrm{ml}$ of DMEM containing BSA. Cells were incubated for $45 \mathrm{~min}$ at $37^{\circ} \mathrm{C}$. Subsequently, the incubation buffer was removed and the cells were washed twice with cold PBS consisting of $138 \mathrm{~mm} \mathrm{NaCl}, 2.7 \mathrm{mM} \mathrm{KCl}, 8 \mathrm{~mm} \mathrm{Na} \mathrm{HPO}_{4}, 1.47$ $\mathrm{mM} \mathrm{KH}_{2} \mathrm{PO}_{4}, 0.5 \mathrm{mM} \mathrm{MgCl}_{2}$, and $0.9 \mathrm{mM} \mathrm{CaCl}_{2}$. The cells were then solubilized in $1 \mathrm{ml}$ of $1 \mathrm{~N} \mathrm{NaOH}$ for $30 \mathrm{~min}$ at room temperature and the cell-associated radioactivity measured. Portions of the sample were used for protein determination. Nonspecific binding was defined as the amount of radioactivity associated with the cells in the presence of 5 $\mu \mathrm{g} / \mathrm{ml}$ of unlabeled NGF. The nonspecific binding was approximately $30 \%$ of the total binding.

Phosphorylation of Nsp100. Cell-free extracts from control and from cells treated with NGF $(50 \mathrm{ng} / \mathrm{ml})$ for $30 \mathrm{~min}$ were prepared as described by Hama et al. (1986), except that the extracts were used without dialysis. The phosphorylation was performed as described by Hama et al. (1986), except that the incubations were terminated by the addition of SDS sample buffer, rather than by trichloroacetic acid.

Protein determination. Protein content was assayed by the method of Bradford (1976), using BSA as a standard.

\section{Results}

$\mathrm{K}-252 \mathrm{a}$, at a concentration of $200 \mathrm{~nm}$, completely inhibited the formation of neurites by PC12 cells treated with NGF (Fig. 1). The inhibition of neurite outgrowth was only partial at $100 \mathrm{~nm}$; at $300 \mathrm{~nm}$ there was loss of cells, the result, apparently, of cytotoxicity.

That the cells were not damaged by $200 \mathrm{~nm} \mathrm{K-252a}$ was shown by the ready reversibility of the effects of that concentration. Removal of K-252a and replacement with medium containing only NGF led to an immediate elaboration of neurites (Fig. 2). The lack of cellular damage could also be seen in experiments in which the incorporation of ${ }^{3} \mathrm{H}$-uridine was measured. Cells treated with $\mathrm{K}-252 \mathrm{a}$ incorporated uridine at the same or even a greater rate than did controls (data not shown), indicating the
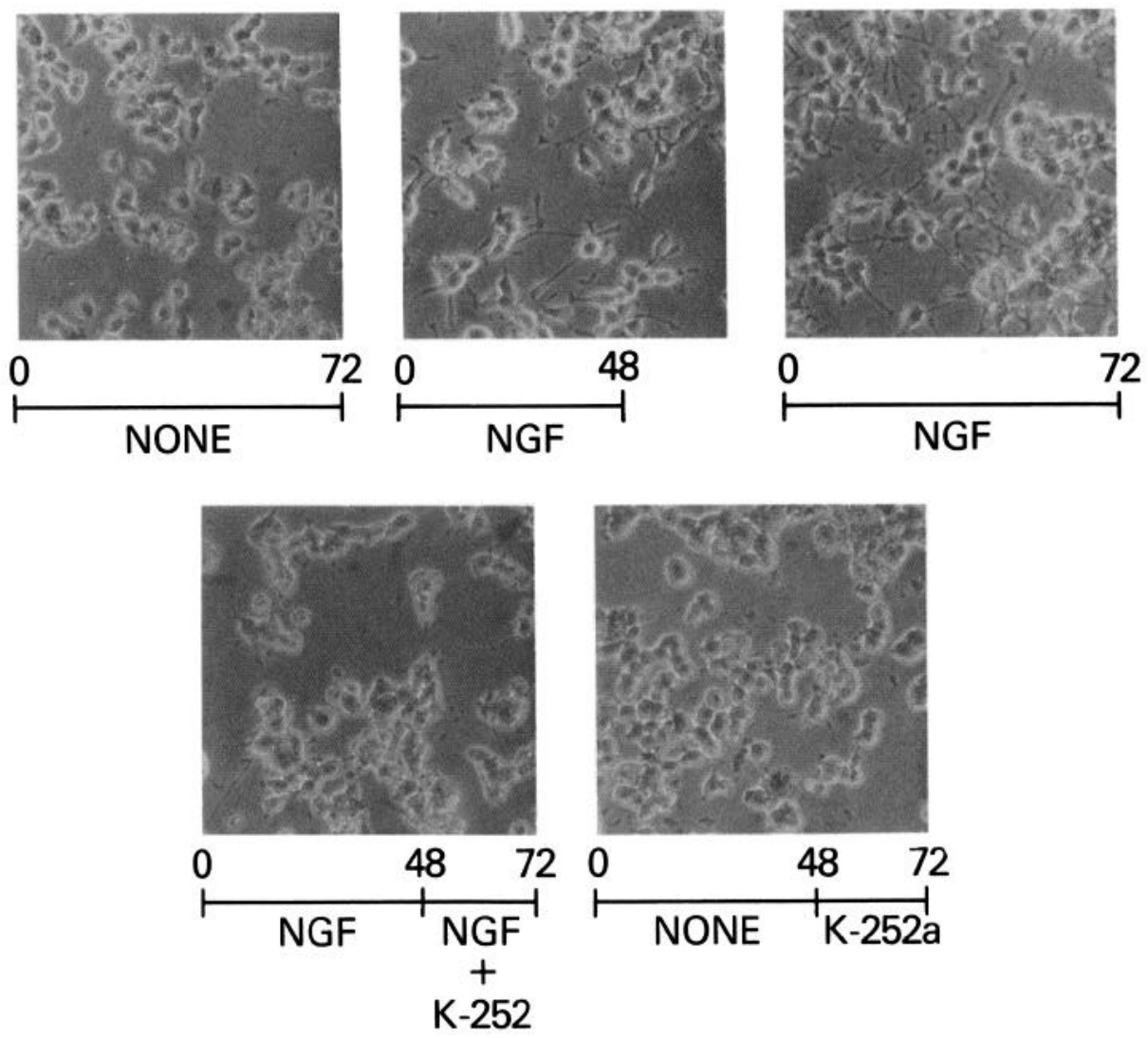

Figure 3. Effect of $\mathrm{K}-252 \mathrm{a}$ on preformed neurites. Cells were grown in the presence or absence of NGF $(50 \mathrm{ng} /$ $\mathrm{ml}$ ) for $48 \mathrm{hr}$, then cultured in the presence or absence of $200 \mathrm{nM} \mathrm{K}-252 \mathrm{a}$ for $24 \mathrm{hr}$. 

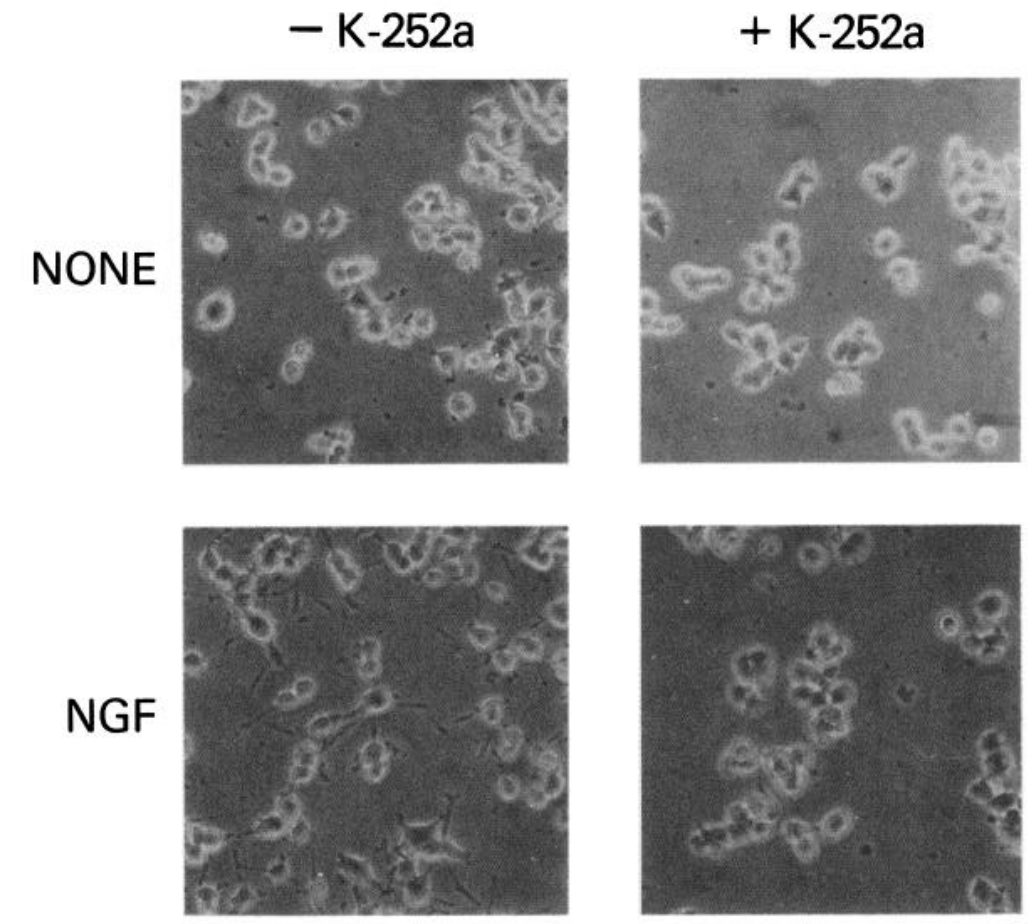

Figure 4. Effect of K-252a on neurite outgrowth produced by FGF. Cells were treated with NGF $(50 \mathrm{ng} / \mathrm{ml})$ or FGF $(50 \mathrm{ng} / \mathrm{ml})$ in the presence or absence of $200 \mathrm{~nm} \mathrm{K-252a.}$
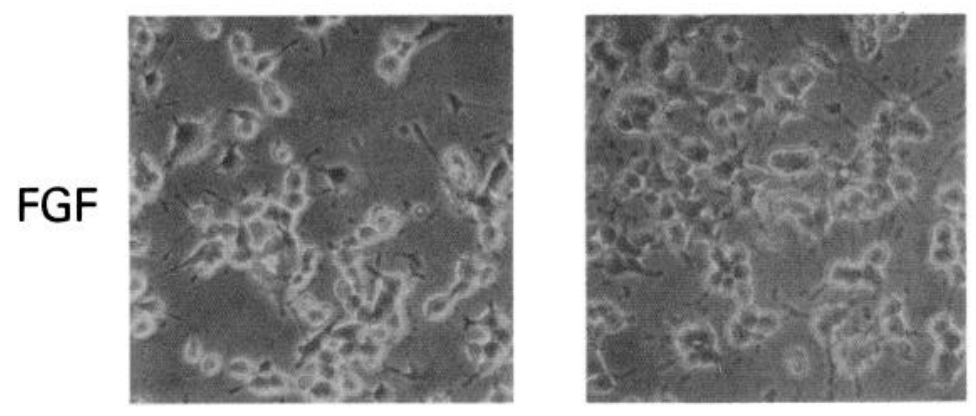

complete integrity of the energy-requiring metabolic pathways in the treated cells.

The addition of K-252a to cells with already formed NGFinduced neurites led to a complete disappearance of these neurites within $24 \mathrm{hr}$ (Fig. 3).

The action of K-252a on neurite formation was specific for neurites elicited by treatment with NGF. In the presence of $\mathrm{K}-252 \mathrm{a}, \mathrm{PC} 12$ cells responded normally to FGF (Fig. 4). Indeed, in these studies it was apparent that the concentration of K-252a that completely blocked the formation of NGF-induced neurites stimulated neurite outgrowth from cells treated with FGF. The outgrowth of processes from cells treated with dBcAMP was also, if anything, enhanced by $\mathrm{K}-252 \mathrm{a}$ (data not shown), although the enhancement was not as apparent as that seen with FGF. Certainly K-252a did not inhibit outgrowth induced by either FGF or dBcAMP. Treatment of the cells with TPA or EGF produced no morphological alterations either in the presence or the absence of K-252a.

The action of $\mathrm{K}-252 \mathrm{a}$ on other NGF-induced processes in PC1 2 cells was investigated. The action of NGF on the induction of ODC was also completely prevented by $200 \mathrm{~nm} \mathrm{K-252a} \mathrm{(Ta-}$ ble 1). This action of K-252a was, furthermore, selective for stimulation by NGF; the induction of ODC by TPA was unaf- fected by the presence of $\mathrm{K}-252 \mathrm{a}$, and the inductions caused by FGF, EGF, and dBcAMP were stimulated by K-252a under the same conditions.

The phosphorylation of a soluble protein, Nsp100, is decreased by treatment of the cells with NGF; this can be seen either in whole cells or in cell-free extracts from treated cells (End et al., 1983). This decrease in phosphorylation can be prevented by simultaneous treatment of the cells with $200 \mathrm{~nm}$ K-252a (Fig. 5).

One of the short-term, transcription-independent actions of NGF, the enhancement of phosphatidylinositol breakdown, was also completely inhibited by $200 \mathrm{~nm} \mathrm{K-252a}$ (Table 2). Again the actions of K-252a appeared specific for NGF-induced events; the stimulation of phosphatidylinositol breakdown caused by EGF not only was not inhibited, it was slightly enhanced.

Even a much longer-term action of NGF, the heterologous down-regulation of the EGF receptor, was blocked by K-252a (Fig. 6). In contrast, the homologous down-regulation of the EGF receptor by EGF was not blocked.

One possible site at which a specific inhibitor of NGF action might act would be at the NGF receptor. However, the presence of $200 \mathrm{~nm} \mathrm{~K}-252 \mathrm{a}$ had no effect on the binding of NGF to PC12 cells at either 820 or 100 pM NGF, concentrations that should 
CONTROL
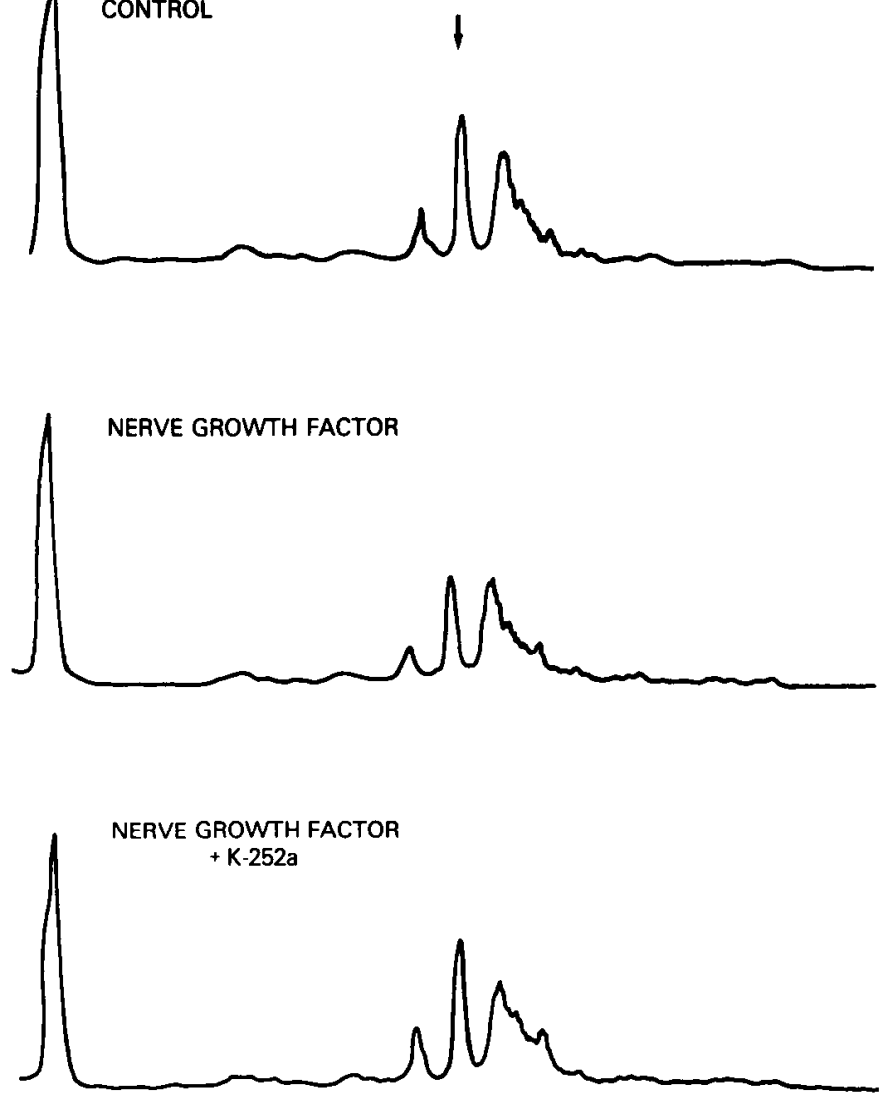

Figure 5. Effect of K-252a on the NGF-induced decrease in the phosphorylation of Nsp100. Cells were treated with NGF $(50 \mathrm{ng} / \mathrm{ml})$ for $30 \mathrm{~min}$. K-252a (200 nM) was also present in the indicated incubation. Phosphorylation was estimated from densitometer scans of autoradiograms of SDS gels. The arrow indicates the position of Nsp 100.

estimate binding to the low affinity "fast" and high-affinity "slow" NGF receptors, respectively (Table 3). K-252a also had no effect on the internalization of NGF (data not shown), a process linked to the "slow" NGF receptor.

\section{Discussion}

The data in this paper clearly show that $\mathrm{K}-252 \mathrm{a}$, under the present conditions and at $200 \mathrm{nM}$ concentration, is a specific inhibitor of the actions of NGF on PC1 2 cells. This is important

Table 1. Effect of K-252a on the induction of ornithine

decarbuxylase in PC12 cells

\begin{tabular}{lcc} 
& \multicolumn{2}{l}{$\begin{array}{l}\text { ODC activity } \\
\text { (pmol/mg protein) }\end{array}$} \\
\cline { 2 - 3 } Treatment & $-\mathrm{K}-252 \mathrm{a}$ & $+\mathrm{K}-252 \mathrm{a}$ \\
\hline None & $5.2 \pm 1.0$ & $5.8 \pm 0.9$ \\
NGF & $55.7 \pm 10.6$ & $4.6 \pm 0.6$ \\
EGF & $17.9 \pm 4.9$ & $35.5 \pm 9.2$ \\
FGF & $49.2 \pm 4.6$ & $84.4 \pm 4.1$ \\
dBcAMP & $171 \pm 8$ & $379 \pm 59$ \\
TPA & $438 \pm 69$ & $375 \pm 37$
\end{tabular}

Mean $\pm \mathrm{SE} ; n=3$. Inducers were used in the following concentrations: NGF (50 $\mathrm{ng} / \mathrm{ml})$ EGF (20 ng/ml); FGF (50 ng/ml); dBcAMP (0.5 mM); TPA (100 ng/ml). Cells were treated with inducers in the presence or absence of $200 \mathrm{nM} \mathrm{K}-252 \mathrm{a}$ for $5 \mathrm{hr}$. The activity of ODC was measured as described in Materials and Methods.

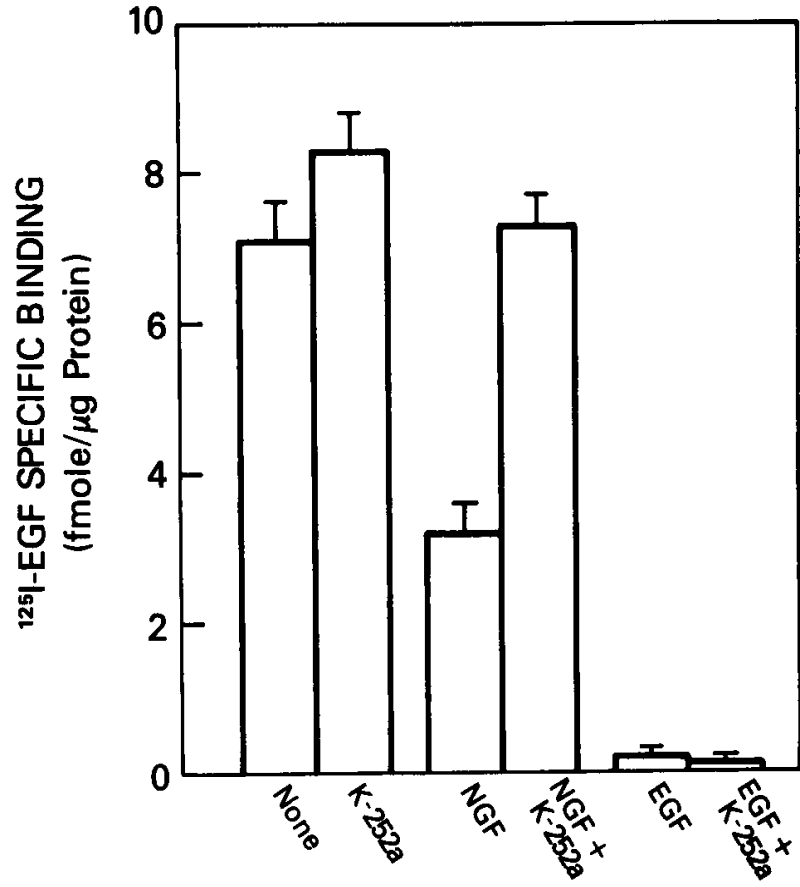

Figure 6. Effect of K-252a on NGF-mediated heterodown-regulation, and EGF-induced homodown-regulation of EGF receptors in PC12 cells. Cells were grown for $48 \mathrm{hr}$ with NGF $(50 \mathrm{ng} / \mathrm{ml})$ or EGF $(600 \mathrm{ng} / \mathrm{ml})$ in the presence or absence of $200 \mathrm{nM} \mathrm{K-252a}$. Binding of ${ }^{125} \mathrm{I}-\mathrm{EGF}(1 \times$ $10^{5} \mathrm{cpm} / \mathrm{ml}$ ) was measured in a $45 \mathrm{~min}$ incubation at $37^{\circ} \mathrm{C}$ in the presence or absence of excess EGF. Monolayers were washed, dissolved in $0.5 \mathrm{~N} \mathrm{NaOH}$, and counted as described in Materials and Methods. Bars indicate SD.

for at least 2 reasons. The first is that an identification and understanding of the mechanisms by which NGF acts will certainly require the availability of inhibitors specific for the NGFinitiated chain of events. The second is that a number of other cffcctors clicit biochemical responses similar to those evoked by NGF, and in order to discern which are peculiar to the specific biological response to NGF, inhibitors are needed that discriminate between these similar-appearing actions of the various effectors.

K-252a appears to be such an inhibitor. At a concentration that demonstrably does not affect the general economy of the cell, K-252a inhibits the NGF-induced increase in phosphatidylinositol breakdown, a rapid, membrane-based action (Contreras and Guroff, 1987), the NGF-induced increase in ODC, a transcriptionally based action (Huff et al., 1981), the NGF-induced decrease in a specific cellular phosphorylation (End et al.,

Table 2. Effect of K-252a on the increase in phosphatidylinositol breakdown in PC12 cells

\begin{tabular}{lll} 
Treatment & $\begin{array}{l}\text { Accumulation of } \\
\text { 3 }\end{array}$ & \\
(\% of control) & \\
\hline None & $-\mathrm{K}-252 \mathrm{a}$ & $+\mathrm{K}-252 \mathrm{a}$ \\
NGF & 100 & $102 \pm 2$ \\
EGF & $195 \pm 9$ & $105 \pm 3$ \\
& $153 \pm 3$ & $176 \pm 8$
\end{tabular}

Mean \pm SE; $n=4$. Cells were treated as described in Materials and Methods, using NGF $(100 \mathrm{ng} / \mathrm{ml})$ or EGF $(50 \mathrm{ng} / \mathrm{ml})$ in the presence or absence of $200 \mathrm{~nm}$ K-252a. 


\begin{tabular}{lll}
\hline $\begin{array}{l}\text { Table 3. } \\
\text { Effect of K-252a on the binding of }\end{array}$ \\
\begin{tabular}{lll}
$\begin{array}{l}\text { 125I-NGF } \\
\text { 125 I-NGF (pM) }\end{array}$ & Treatment & $\begin{array}{l}\text { NGF binding } \\
\text { (pmol/mg protein) }\end{array}$ \\
\hline 820 & None & $0.553 \pm 0.005$ \\
& K-252a & $0.555 \pm 0.007$ \\
100 & None & $0.138 \pm 0.006$ \\
& K-252a & $0.134 \pm 0.005$
\end{tabular}
\end{tabular}

PC12 cells were incubated with 820 or 100 pM ${ }^{125}$ I-NGF in the presence or absence of 200 nM K-252a. The values shown are means \pm SEM for 3 determinations.

1983), the NGF-induced heterodown-regulation of the EGF receptor (Huff et al., 1981), and the NGF-elicited generation of neurites, an action of the factor that requires both membrance and nuclcar events (Burstein and Greene, 1978).

Further, K-252a appears to be quite selective for the actions of NGF. Phosphatidylinositol breakdown in PC12 cells is enhanced by EGF, as well as by NGF. But while the response to NGF is blocked by $\mathrm{K}-252 \mathrm{a}$, the EGF response is not only not inhibited, it is, in fact, stimulated. ODC is induced by any number of effectors; of those studied here, only the response to NGF was inhibited. EGF receptors are down-regulated by both NGF and EGF, but only the former action is prevented by $\mathrm{K}-252 \mathrm{a}$. Neurite outgrowth from $\mathrm{PC} 12$ cells is produced by treatment with FGF, although the temporal course of the outgrowth is different than that of neurite outgrowth produced by treatment with NGF (Togari and Guroff, 1985). Nevertheless, the induction of processes by FGF is not altered by the presence of K-252a.

Inhibitors selective for the action of NGF, or, for that matter, for any of the several growth factors now known, are few and far between. In the case of NGF only 3 inhibitors have been described. Lithium ion has been reported to inhibit NGF-induced neurite outgrowth by Burstein et al. (1985), but in the same report it was shown that lithium has no effect on the other actions of the factor. Activators of adenylate cyclase also inhibit some, but not all, NGF-induced responses (Greene et al., 1986). Inhibitors of methyltransferase reactions have been shown to inhibit all NGF actions in PC12 cells-both short-term, membrane-based and longer-term, transcriptionally based (Seeley et al., 1984). This inhibition by methyltransferase inhibitors has a specificity and characteristics similar to those seen with $\mathrm{K}-252 \mathrm{a}$. The exact site of the action of the methyltransferase inhibitors has not been reported, but it has been suggested that the inhibited reaction leads to the methylation of protein and not to that of lipid (Seeley et al., 1984).

The site of action of $\mathrm{K}-252 \mathrm{a}$ is also not clear. The first information available about this compound suggested that it was a selective inhibitor of protein kinase C (Kase et al., 1986). More recent studies have indicated a more general action on kinases (Kase et al., 1987). Indeed, the recent information suggests that the compound inhibits kinases in a rather nonspecific way, by competing for ATP (Kase et al., 1987; Yamada et al., 1987).

In the light of the present studies we know some sites at which $\mathrm{K}-252 \mathrm{a}$ does not act under the conditions we have described. $\mathrm{K}-252 \mathrm{a}$ does not have a general cytotoxic action on the cells, nor does it interfere with energy metabolism. This can be seen from the fact that the induction of ODC by EGF, or the incorporation of uridine into RNA, both energy-requiring reactions, is not inhibited by $\mathrm{K}-252 \mathrm{a}$. The uridine experiments also in- dicate that $\mathrm{K}-252 \mathrm{a}$, under the conditions of the present study, is not an inhibitor of RNA synthesis. K-252a is also not a receptor antagonist, since the binding of NGF to its $\mathrm{PC} 12$ receptor was not inhibited by $200 \mathrm{nM} \mathrm{K}-252 \mathrm{a}$. This experiment also rules out the trivial explanation that $\mathrm{K}-252 \mathrm{a}$ is in some way binding, or alters NGF in the medium, thus making it unavailable to the cells. The present data may also rule out the actions of $\mathrm{K}-252 \mathrm{a}$ at $200 \mathrm{nM}$, under the present conditions, as an inhibitor of either protein kinase $\mathrm{C}$ or cAMP-dependent kinase, since both TPA and dBcAMP exert their normal actions on ODC even in the presence of K-252a.

The exact site of inhibition, then, is still a matter of speculation and study. At this point, it seems likely that K-252a inhibits either a kinase unique to the pathway by which NGF acts, a different ATP-requiring reaction, or even a methyltransferase. This latter explanation appears to be a possibility, since both K-252a and the methyltransferase inhibitors not only inhibit NGF-requiring reactions, but stimulate the comparable actions of other ligands, such as EGF (Seeley et al., 1984). One important difference, however, is that the methyltransferase inhibitors inhibit the action of FGF on PC12 cells (Togari et al., 1985); K-252a clearly does not. Also, K-252a at 200 nM did not have any effect on the level of methylation from methyl-labeled methionine in intact $\mathrm{PC} 12$ cells under conditions in which methylthioadenosine blocked methylation virtually $100 \%$. Whatever reaction is the target for $\mathrm{K}-252 \mathrm{a}$, it must be very closely associated with the receptor, since all the actions of NGF, even the very short-term ones, are inhibited.

In conclusion, then, $\mathrm{K}-252 \mathrm{a}$, under the present conditions, inhibits the actions of NGF on PC12 cells. Indeed, $\mathrm{K}-252 \mathrm{a}$ is so selective that it is able to discriminate between the actions of NGF and those of several other effectors, even though the end result of these actions-phosphatidylinositol breakdown, ODC induction, receptor down-regulation, or neurite outgrowth - is apparently the same. When the site of $\mathrm{K}-252 \mathrm{a}$ action is discovered, it should put us one step closer to understanding the mechanism of action of NGF.

\section{References}

Aloe, L., and R. Levi-Montalcini (1979) Nerve growth factor-induced transformation of immature chromaffin cells in vivo into sympathetic neurons: Effect of antiserum to nerve growth factor. Proc. Natl. Acad. Sci. USA 76: $1246-1250$.

Armelin, H. A., K. Nishikawa, and G. H. Sato (1974) Control of mammalian cell growth in culture: The action of protein and steroid hormones as effector substances. In Control of Proliferation in Animal Cells, B. Clarkson and R. Baserga, eds., pp. 97-104, Cold Spring Harbor, New York.

Berridge, M. J., R. M. C. Dawson, C. P. Downes, J. P. Helson, and R. R. Irvine (1983) Changes in the levels of inositol phosphates after agonist-dependent hydrolysis of membrane phosphoinositide. Biochem. J. 212: 473-482.

Bocchini, V., and P. U. Angeletti (1969) The nerve growth factor: Purification as a 30,000 molecular weight protein. Proc. Natl. Acad. Sci. USA 64: 787-794.

Bradford, M. M. (1976) A rapid and sensitive method for the quantitation of microgram quantities of protein utilizing the principle of protein-dye binding. Anal. Biochem. 72: 248-254.

Burstein, D. C., and L. A. Greene (1978) Evidence for RNA synthesisdependent and -independent pathways in stimulation of neurite outgrowth by nerve growth factor. Proc. Natl. Acad. Sci. USA 75: 60596063.

Burstein, D. E., P. J. Scelcy, and L. A. Greene (1985) Lithium ion inhibits nerve growth factor-induced neurite outgrowth and phosphorylation of nerve growth factor-modulated microtubule-associated proteins. J. Cell Biol. 101: 862-879. 
Contreras, M. L., and G. Guroff (1987) Calcium-dependent nerve growth factor-stimulated hydrolysis of phosphoinositides in PC12 cells. J. Neurochem. 48: 1466-1472.

Cremins, J., J. A. Wagner, and S. Halegoua (1986) Nerve growth factor action is mediated by cyclic AMP- and $\mathrm{Ca}^{+2} /$ phospholipid-dependent protein kinases. J. Cell Biol. 103: 887-893.

End, D., N. Tolson, S. Hashimoto, and G. Guroff (1983) Nerve growth factor-induced decrease in the cell-free phosphorylation of a soluble protein in PC12 cells. J. Biol. Chem. 258: 6549-6555.

Greenberg, M. E., L. A. Greene, and E. B. Ziff (1985) Nerve growth factor and epidermal growth factor induce rapid transient changes in proto-oncogene transciption in PC1 2 cells. J. Biol. Chem. 260: 1410114110.

Greene, L. A., and E. M. Shooter (1980) The nerve growth factor: Biochemistry, synthesis and mechanism of action. Annu. Rev. Neurosci. 3: 353-402.

Greene, L. A., and A. S. Tischler (1976) Establishment of a noradrenergic clonal line of rat adrenal pheochromocytoma cells which respond to nerve growth factor. Proc. Natl. Acad. Sci. USA 73: 24242428.

Greene, L. A., and A. S. Tischler (1982) PC12 pheochromocytoma cultures in neurobiological research. In Advances in Cellular Neurobiology, S. Federoff, and L. Hertz, eds., pp. 373-414, Academic, New York.

Greene, L. A., S. A. Drexler, J. L. Connolly, A. Rukenstein, and S. H. Green (1986) Selective inhibition of responses to nerve growth factor and of microtubule-associated protein phosphorylation by activators of adenylate cyclase. J. Cell Biol. 103: 1967-1978.

Gunning, P. W., G. E. Landreth, M. Bothwell, and E. M. Shooter (1981) Differential and synergistic actions of nerve growth factor and cyclic AMP in PC12 cells. J. Cell Biol. 89: 240-245.

Guroff, G. (1984) PC1 2 cells as a model of neuronal differentiation. In Cell Culture in the Neurosciences. J. Bottenstein and G. Sato, eds. pp. 245-271, Plenum, New York.

Halegoua, S., and J. Patrick (1980) Nerve growth factor mediates phosphorylation of specific proteins. Cell 22: 571-581.

Hama, T., K.-P. Huang, and G. Guroff (1986) Protein kinase C as a component of a nerve growth factor-sensitive phosphorylation system in PC1 2 cells. Proc. Natl. Acad. Sci. USA 83: 2353-2357.

Hefti, F, J. Hartikka, F. Eckenstein, H. Gnahn, R. Heumann, and M. Schwab (1985) Nerve growth factor increases choline acetyltransferase but not survival or fiber outgrowth of cultured fetal septal cholinergic neurons. Neuroscience 14: 55-68.

Huff, K., D. End, and G. Guroff (1981) Nerve growth factor-induced alteration in the response of PC12 pheochromocytoma cells to epidermal growth factor. J. Cell Biol. 88: 189-198.

Kase, H., K. Iwahashi, and Y. Matsuda (1986) K-252a, a potent inhibitor of protein kinase $C$ from microbial origin. J. Antibiot. (Tokyo) 39: 1059-1065.

Kase, H., K. Iwahashi, S. Nakanishi, Y. Matsuda, K. Yamada, M. Takahashi, C. Murakata, A. Kato, and M. Kaneko (1987) K-252 compounds, novel and potent inhibitors of protein kinase $\mathrm{C}$ and cyclic nucleotide-dependent protein kinases. Biochem. Biophys. Res. Commun. 142: 436-440.

Landreth, G. E., and G. D. Rieser (1985) Nerve growth factor- and epidermal growth factor-stimulated phosphorylation on PC12 cytoskeletally associated protein in situ. J. Cell Biol. 100: 677-683.

Lazarovici, P., G. Dickens, H. Kuzuya, and G. Guroff (1987) Long- term, heterologous down-regulation of the epidermal growth factor receptor in PC1 2 cells by nerve growth factor. J. Cell Biol. 104: 16111621 .

Lee, K. Y., P. J. Seeley, T. H. Muller, E. Helmer-Matyjek, E. Sabban, M. Goldstein, and L. A. Greene (1985) Regulation of tyrosine hydroxylase phosphorylation in PC12 pheochromocytoma cells by elevated $\mathrm{K}+$ and nerve growth factor. Evidence for different mechanisms of action. Mol. Pharmacol. 28: 220-228.

Levi-Montalcini, R. (1966) The nerve growth factor, its mode of action on sensory and sympathetic nerve cells. Harvey Lect. 60: 217-259.

Martinez, H. J., C. F. Dreyfus, G. M. Jonakait, and I. B. Black (1985) Nerve growth factor promotes cholinergic development in brain striatal culture. Proc. Natl. Acad. Sci. USA 82: 7777-7781.

Matsuda, Y., and G. Guroff (1987) Purification and mechanism of activation of a nerve growth factor-sensitive S6 kinase from PC12 cells. J. Biol. Chem. 262: 2832-2844.

Matsuda, Y., N. Nakanishi, G. Dickens, and G. Guroff (1986) A nerve growth factor-sensitive S6 kinase in cell-free extracts from PC1 2 cells. J. Neurochem. 47: 1728-1734.

Nakanishi, N., and G. Guroff (1985) Nerve growth factor-induced increase in the cell-free phosphorylation of a nuclear protein in $\mathrm{PC} 12$ cells. J. Biol. Chem. 260: 7791-7799

Oka, Y., and J. W. Perry (1976) Studies on regulatory factors of ornithine decarboxylase activity during development of mouse mammary epithelium in vitro. J. Biol. Chem. 251: 1738-1 744.

Pegg, A. E., and H. G. Williams-Ashman (1968) Biosynthesis of putrescine in the prostate gland of rat. Biochem. J. 108: 533-539.

Schubert, D., S. Heinemann, and Y. Kidokoro (1977) Cholinergic metabolism and synapse formation by a rat nerve cell line. Proc. Natl. Acad. Sci. USA 74: 2579-2583.

Seeley, P. J., A. Kukenstein, J. Connolly, and L. A. Greene (1984) Differential inhibition of nerve growth factor and epidermal growth factor effects on the PC12 pheochromocytoma line. J. Cell Biol. 98: 417-426.

Sutter, A., R. J. Riopelle, R. M. Harris-Warrick, and E. M. Shooter (1979) Nerve growth factor. Characterization of two distinct classes of binding sites on chick embryo sensory ganglion cells. J. Biol. Chem. 254: 5979-5982.

Togari, A., and G. Guroff (1985) Partial purification and characterization of a nerve growth factor-sensitive kinase and its substrate from PC1 2 cells. J. Biol. Chem. 260: 3804-3811.

Togari, A., G. Dickens, H. Kuzuya, and G. Guroff (1985) The effect of fibroblast growth factor on PC12 cells. J. Neurosci. 5: 307-316.

Unsicker, K., B. Krisch, U. Otten, and H. Thoenen (1978) Nerve growth factor-induced outgrowth from isolated rat adrenal chromaffin cells: Impairment by glucocorticoids. Proc. Natl. Acad. Sci. USA 75: 3498-3502.

Vale, R. D., and E. M. Shooter (1985) Assaying binding of nerve growth factor to cell surface receptors. Methods Enzymol. 109: 2139.

Yamada, K., K. Iwahashi, and H. Kase (1987) K-252a, a new inhibitor of protein kinase $\mathrm{C}$, concomitantly inhibits $40 \mathrm{~K}$ protein phosphorylation and serotonin secretion in phorbol ester-stimulated platelets. Biochem. Biophys. Res. Commun. 144: 35-40.

Yu, M. W., N. Tolson, and G. Guroff (1980) Increased phosphorylation of specific nuclear proteins in superior cervical ganglia and $\mathrm{PC1} 2$ cells in response to nerve growth factor. J. Biol. Chem. 255: 1048110492. 